\title{
Improvement of Unsaturated Fatty Acid Production from Porphyridium cruentum Using a Two-Phase Culture System in a Photobioreactor with Light-Emitting Diodes (LEDs)
}

\author{
So Hee Kim, Ui Hun Lee, Sang Baek Lee, Gwi-Taek Jeong, and Sung-Koo Kim* \\ School of Marine, Fisheries and Life Science, Pukyong National University, Busan 48513, Republic of Korea
}

In this study, the culture conditions for Porphyridium cruentum were optimized to obtain the maximum biomass and lipid productions. The eicosapentaenoic acid content was increased by pH optimization. $P$. cruentum was cultured with modified F/2 medium in 14-L photobioreactors using a two-phase culture system, in which the green $(520 \mathrm{~nm})$ and red $(625 \mathrm{~nm})$ light-emitting diodes (LEDs) were used during the first and second phases for biomass production and lipid production, respectively. Various parameters, including aeration rate, light intensity, photoperiod, and pH were optimized. The maximum biomass concentration of $0.91 \mathrm{~g} \mathrm{dcw} / \mathrm{l}$ was obtained with an aeration rate of $0.75 \mathrm{vvm}$, a light intensity of $300 \mathrm{\mu mol} \mathrm{m}^{-2} \mathrm{~s}^{-1}$, and a photoperiod of 24:0 $\mathrm{h}$. The maximum lipid production of $51.8 \%(\mathrm{w} / \mathrm{w})$ was obtained with a light intensity of $400 \mu \mathrm{mol} \mathrm{m} \mathrm{m}^{-2} \mathrm{~s}^{-1}$ and a photoperiod of 18:6 h. Additionally, the eicosapentaenoic acid and unsaturated fatty acid contents reached $30.6 \%$ to $56.2 \%$ at $\mathrm{pH} 6.0$.

Keywords: Light-emitting diodes (LEDs), unsaturated fatty acids, photobioreactor, Porphyridium cruentum, eicosapentaenoic acid

Received: November 2, 2020 Accepted: December 3, 2020

First published online: December 7, 2020

*Corresponding author Phone: +82-51-629-5868 Fax: + 82-51-629-5863 E-mail: skkim@pknu.ac.kr

pISSN 1017-7825 elSSN 1738-8872

Copyright(C) 2021 by The Korean Society for Microbiology and Biotechnology

\section{Introduction}

Unsaturated fatty acids are the essential components of higher eukaryotic cells [1]. The unsaturated fatty acid omega-3 ( $\omega$-3) consists of $\alpha$-linolenic acid $\left(\mathrm{C}_{18} \mathrm{H}_{30} \mathrm{O}_{2}\right.$, ALA), eicosapentaenoic acid $\left(\mathrm{C}_{20} \mathrm{H}_{30} \mathrm{O}_{2}, \mathrm{EPA}\right)$, and docosahexaenoic acid $\left(\mathrm{C}_{22} \mathrm{H}_{32} \mathrm{O}_{2}\right.$, DHA). ALA can lower blood cholesterol levels and thus reduce the risk of cardiovascular diseases and protect arteries [2]. EPA can reduce blood cholesterol and triglyceride levels to suppress blood clot formation and stimulate brain function. EPA has been shown to prevent diseases such as arteriosclerosis and lung disease [3]. DHA is one of the major components of the cell membrane and is primarily found in the brain and retina. Indeed, it is one of the important components of the brain [4]. Currently, the major source of both EPA and DHA is marine fish, such as mullet, salmon, and mackerel [5]. However, overfishing has exponentially increased since the 1980s worldwide. Therefore, the use of fish as the primary source of unsaturated fatty acids is no longer a sustainable option [6]. As a result, aquaculture has become one of the fastest growing food industries in the world [7]. Soybean meal, rapeseed, sunflower seeds and corn are used as feed for aquaculture, however, they are not suitable for this purpose because they are food crops in limited supply. Thus, microalgae have potential as a sustainable and economical feed source $[8,9]$. Consequently, microalgae have increasingly attracted attention due to their EPA and DHA contents.

Microalgae are primary producers found in most oceans. They use light energy and carbon dioxide to convert biomass into carbohydrates, proteins, and lipids [10]. Biomasses can be used as biofuel, food, and feed resources [11]. In addition, microalgae absorb carbon dioxide 10-50 times faster than land plants and can help solve environmental problems such as global warming [12]. Here, we investigated the microalga Porphyridium cruentum due to its high lipid content per dry cell weight (30-40\%), rapid proliferation, and high percentage of $\omega$ 3 fatty acids [6]. Most microalga strains have been isolated and cultured under controlled conditions for efficient cultivation. Photobioreactors (PBRs) can adjust the culture conditions for microalga strains and control the metabolism of microalgae [13]. Moreover, bioreactors with light-emitting diodes (LEDs) have been used for the efficient cultivation of microalgae. However, it is not clear whether the LED chip can supply enough light energy to penetrate the $20-\mathrm{mm}$ thick bioreactor wall and enter into the chamber [14, 15]. In addition, when the cell concentration is high, it is difficult to transmit light to the inside of the reactor using an external light source. To solve this issue, we used a photobioreactor equipped with an internal light source. Optimization of the LED light 
intensity, photoperiod, and wavelength improved lipid production and microalgae growth [16]. According to previous studies, $P$. cruentum reaches the highest biomass at the green LED wavelength $(520 \mathrm{~nm})$. The phycobiliproteins of $P$. cruentum are composed of phycoerythrin, phycocyanin, and small amounts of allophycocyanin. Phycoerythrin efficiently absorbs light in the green LED wavelength $(520 \mathrm{~nm})$ to reach high biomass [17].

In this study, we employed a two-phase culture system involving 14-L photobioreactors (PBRs) to cultivate P. cruentum. In the first phase, we used a green $(520 \mathrm{~nm})$ LED to increase the biomass production, and then the LED wavelength was switched to red $(625 \mathrm{~nm})$ during the second phase to stimulate lipid production. The optimization of the aeration rate, light intensity, and photoperiod increased the biomass production, while the optimization of the light intensity, photoperiod, and $\mathrm{pH}$ increased the lipid production. Finally, we evaluated the effect of $\mathrm{pH}$ on the production of $\omega-3$ fatty acids.

\section{Materials and Methods}

\section{Microalgal Strain and Culture Conditions}

P. cruentum was obtained from the Korea Institute of Ocean Science \& Technology (Kiost, Korea) and precultured for 10 days in sterilized seawater with modified $\mathrm{F} / 2$ medium containing $75 \mathrm{mg} \mathrm{NaNO}, 5 \mathrm{mg} \mathrm{NaH} \mathrm{PO}_{4} \cdot \mathrm{H}_{2} \mathrm{O}$, $4.36 \mathrm{mg} \mathrm{Na} 2 \mathrm{EDTA}, 3.15 \mathrm{mg} \mathrm{FeCl} \cdot 6 \mathrm{H}_{2} \mathrm{O}, 0.02 \mathrm{mg} \mathrm{\textrm {MCl } _ { 2 }} \cdot 4 \mathrm{H}_{2} \mathrm{O}, 0.02 \mathrm{mg} \mathrm{ZnSO} \cdot 7 \mathrm{H}_{2} \mathrm{O}, 0.01 \mathrm{mg} \mathrm{CoCl} \cdot 6 \mathrm{H}_{2} \mathrm{O}$, $0.01 \mathrm{mg} \mathrm{CuSO}_{4} \cdot 5 \mathrm{H}_{2} \mathrm{O}, 0.006 \mathrm{mg} \mathrm{Na}_{2} \mathrm{MoO}_{4} \cdot 2 \mathrm{H}_{2} \mathrm{O}, 30 \mathrm{mg} \mathrm{Na}_{2} \mathrm{SiO}_{3}, 0.2 \mathrm{mg}$ thiamine- $\mathrm{HCl}, 0.01 \mathrm{mg}$ vitamin $\mathrm{B}_{12}$, and $0.1 \mathrm{mg}$ biotin per liter [18]. The experiment was carried out with a working volume of $10 \mathrm{~L}$ in 14 -L PBRs at $20^{\circ} \mathrm{C}$ and $150 \mathrm{rpm}$. The initial cell density was $1 \times 10^{5} \mathrm{cells} / \mathrm{ml}$. The cultivation process was aimed at maximum biomass production in the first phase of the culture, and maximum lipid production and polyunsaturated fatty acid (PUFA) production in the second phase.

\section{PBR and Illumination System}

Each PBR (FMT ST series, Fermentec Co. Ltd., Korea) was made of Pyrex glass with an internal diameter and height of $200 \mathrm{~mm}$ and $450 \mathrm{~mm}$, respectively, as shown in Fig. 1A. Filtered air was supplied through a ring sparger at the bottom of the tank, and the aeration rate was controlled by a rotameter. The agitation system consisted of 2disk turbine impellers and a foam breaker. To enhance mixing, three baffles were set at the bottom of the PBR. The external LED panels used in this experiment had a size of $28.5 \times 38.6 \times 4.4 \mathrm{~cm}^{3}$ (Luxpia Co. Ltd., Korea) and were arranged in strips as shown in Figs. 1B and 1C. Each LED strip comprised 20 diodes spaced at $1-\mathrm{cm}$ intervals vertically and horizontally. Additionally, considering the light transmittance, an LED strip composed of 30 diodes spaced vertically $1-\mathrm{cm}$ apart was installed in the photobioreactor as shown in Fig. 1D. The green LED wavelength $(520 \mathrm{~nm})$ was used during the first phase for biomass production (Fig. 1E), and the red LED wavelength (625 nm) during the second phase for lipid production (Fig. 1F). Light intensity was measured at the center of the PBR by a light sensor (HD2102.2; Ohm S.R.L., Italy).

\section{Experimental Design}

A two-phase culture system was used to enhance the biomass, lipid, and PUFA yields from P. cruentum. Toward this end, culture conditions were separately optimized for each of the two phases. In the first phase, various growth conditions, including the aeration rate $(0.25,0.50$, and 0.75 vessel volumes per minute; vvm), light intensity ( 100 , $200,300,400,500$, and $\left.600 \mu \mathrm{mol} \mathrm{m}^{-2} \mathrm{~s}^{-1}\right)$, and photoperiod cycle $(12: 12,18: 6$, and 24:0 h) based on the green LED wavelength $(520 \mathrm{~nm})$ were evaluated for the maximum cell growth. After determining the optimal aeration rate, light intensity, and photoperiod cycle for the cell growth in the first phase of the culture, the conditions for the lipid production were optimized in the second phase by controlling the light intensity $(100,200,300,400,500$, and

A

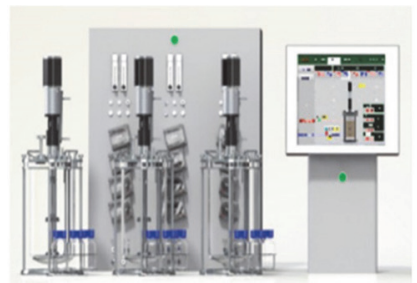

D

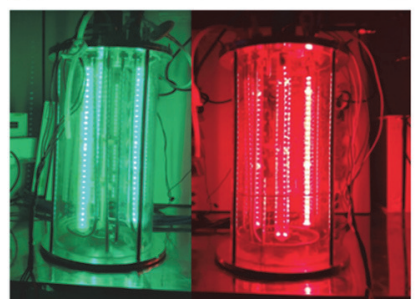

B

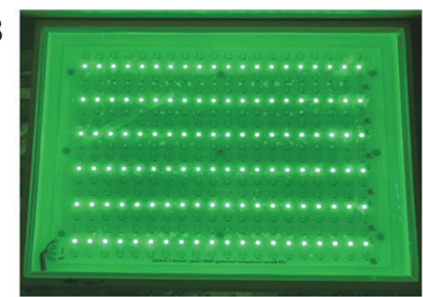

E

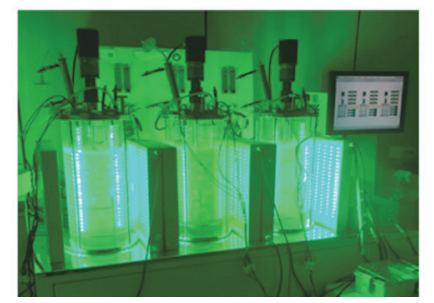

C

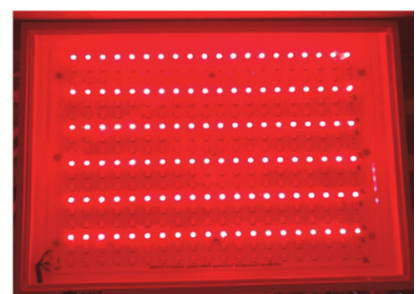

F

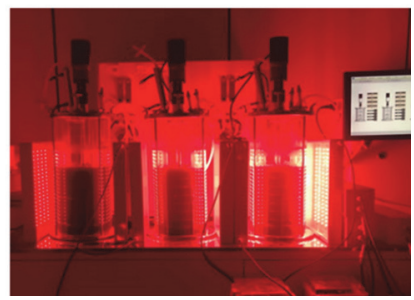

Fig. 1. Application of three 14-L photo-bioreactors. (A) Graphical photographs of the 14-L photo-bioreactors. Photographs of the microalgae grown with external (B) green $(520 \mathrm{~nm})$ and $(\mathbf{C})$ red LED $(625 \mathrm{~nm})$ panels and $(\mathbf{D})$ internal LED light during the (E) first phase under the green LED wavelength for biomass culture and the (F) second phase under the red LED wavelength for lipid accumulation. 
$\left.600 \mu \mathrm{mol} \mathrm{m}^{-2} \mathrm{~s}^{-1}\right), \mathrm{pH}(5.0,6.0,7.0,8.0$, and 9.0), and photoperiod cycle (12:12, 18:6, and 24:0 h) using the red LED wavelength $(625 \mathrm{~nm})$. The aeration rate, light intensity, and photoperiod were optimized to carry out the first phase culture until day 7. The second phase culture was then carried out from day 8 onward at $\mathrm{pH} 5.0$ using the citrate buffer, at $\mathrm{pH} 6.0,7.0$, or 8.0 using the potassium phosphate buffer, and at $\mathrm{pH} 9.0$ using the tris(hydroxymethyl) aminomethane buffer as previously described [19]. Untreated cultures were used as controls. The end of the first phase was defined as the point at which the cells reached the stationary phase due to the depletion of the nitrogen source. When the cell growth reaches the stationary phase, the second phase is initiated to produce lipids.

\section{Assessment of Microalgal Growth}

Dry cell weight was determined by an ultraviolet-visible spectrophotometer (Ultrospec 6300 Pro; Biochrom Ltd., UK) at an optical density of $540 \mathrm{~nm}\left(\mathrm{OD}_{540}\right)$ [20].

The correlation equation $\left(\mathrm{R}^{2}=0.99\right)$ for the dry cell weight of P. cruentum at $\mathrm{OD}_{540}$ is shown below in Eq. (1):

Dry cell weight (dcw) of P. cruentum $\left(g d c w L^{-1}\right)=0.77\left(O D_{540}\right)\left(R^{2}=0.99\right)$

\section{Assessment of Total Lipid Content}

Cells were harvested using a centrifuge (Supra R22; Hanil Scientific Inc., Korea) at 8,000 $\times g$ for 10 min. The precipitated biomass was washed with distilled water twice and then dried in a freeze dryer (SFDSM-24L; SamWon Industry, Korea). Subsequently, $5 \mathrm{~mL}$ of distilled water was added to $10 \mathrm{mg}$ of dried cell biomass, which was then sonicated for $10 \mathrm{~min}$ using a sonicator $(100 \mathrm{~W}, 20 \mathrm{kHz}, 550$ Sonic Dismembrator; Fisher Scientific Inc., USA). Total lipid content (\% of DCW) was determined using methanol and chloroform following a modified solvent-based method [21] as shown in Eq. (2).

$$
\text { Lipid content }(\% \text { of } d c w)=\frac{\left(W_{2}-W_{1}\right) \times 100}{D C W}
$$

$\mathrm{W}_{1}(\mathrm{~g})$ is the weight of the empty 20 -ml glass tube, and $\mathrm{W}_{2}(\mathrm{~g})$ is the weight of the tube with extracted lipids. DCW $(\mathrm{g})$ is the dried microalgal biomass.

\section{Fatty Acid Methyl Ester (FAME) Measurement}

The direct transesterification method reported by Dhup and Dhawan [22] was used to convert extracted lipids to FAMEs. FAMEs were then analyzed using gas chromatography (GC, YL 6100; Young Lin Inc., Korea) by employing a flame ionization detector (FID) and a silica capillary column $(30 \mathrm{~m} \times 0.32 \mathrm{~mm} \times 0.5 \mu \mathrm{m}$, HPINNOWAX; Agilent Technologies, USA). The column temperature was adjusted as follows: $140^{\circ} \mathrm{C}$ for $5 \mathrm{~min}$, followed by an incremental temperature increase to $240^{\circ} \mathrm{C}$ at a rate of $5^{\circ} \mathrm{C} / \mathrm{min}$ and subsequent incubation at $240^{\circ} \mathrm{C}$ for $10 \mathrm{~min}$. The injector and FID temperatures were set at $250^{\circ} \mathrm{C}$. FAMEs were identified by comparing their retention times against those of authentic standards.

\section{Statistical Analyses}

Each experiment was conducted in triplicate. The statistical significance of the cell biomasses and lipid contents were evaluated by one-way analysis of variance (ANOVA) and Duncan's multiple range test $(p<0.05)$ using SPSS software (ver. 23.0; SPSS Inc., USA).

\section{Results and Discussion}

\section{Effect of Aeration Rate Under Green LED Wavelength}

The photoperiod was set at a $12: 12 \mathrm{~h}$ light/dark cycle, with a light intensity of $100 \mu \mathrm{mol} \mathrm{m} \mathrm{s}^{-2}$. Following aeration rate optimization, the photoperiod and light intensity were optimized as well. Aeration rates of $0.25,0.50$, and $0.75 \mathrm{vvm}$ were tested with a green LED wavelength $(520 \mathrm{~nm})$. Fig. $2 \mathrm{~A}$ shows that cells with $0.75 \mathrm{vvm}$ aeration rate produce the highest biomass of $P$. cruentum $(0.40 \mathrm{~g} \mathrm{dcw} / \mathrm{l})$ by day 14 , followed by $0.50 \mathrm{vvm}(0.38 \mathrm{~g} \mathrm{dcw} / \mathrm{l})$ and then $0.25 \mathrm{vvm}(0.20 \mathrm{~g} \mathrm{dcw} / \mathrm{l})$. These results indicate that the $\mathrm{CO}_{2}$ supply should be well mixed with the culture. Microalgal biomass production is enhanced by sufficient $\mathrm{CO}_{2}$ supply and aeration. However, excessive aeration rates can cause shear stress to the cells, causing cell damage [23]. Sirisuk et al. [15] reported that increasing the aeration rate from $0.25 \mathrm{vvm}$ to $0.50 \mathrm{vvm}$ increases the cellular biomass from $0.33 \mathrm{~g} \mathrm{dcw} / \mathrm{l}$ to $0.38 \mathrm{~g} \mathrm{dcw} / \mathrm{lin}$ Nannochloropsis oceanica cultures. To obtain large microalgal biomasses, a high aeration rate and a high level of $\mathrm{CO}_{2}$ are required; however, the aeration rate must be limited due to the eventual cell damage [24]. The maximum biomass in this study was achieved with a $0.75 \mathrm{vvm}$ aeration rate, and the $\mathrm{CO}_{2}$ aeration rate was set to this optimal value to obtain the largest microalgal biomass from our culture.

\section{Effect of Green LED Light Intensity Under Green LED Wavelength}

After determining the optimal aeration rate, the effect of light intensity on biomass production was evaluated. $P$. cruentum was cultured at the optimum aeration rate of $0.75 \mathrm{vvm}$ with the green LED wavelength. Light intensities of 100, 200, 300, 400, 500, and $600 \mu \mathrm{mol} \mathrm{m}^{-2} \mathrm{~s}^{-1}$ were tested in this study. Fig. 2B shows that P. cruentum produced $0.75 \mathrm{~g} \mathrm{dcw} / \mathrm{l}$ of biomass by day 12 with $300 \mu \mathrm{mol} \mathrm{m}^{-2} \mathrm{~s}^{-1}$ of light intensity, followed by $0.74,0.73,0.72,0.50$, and $0.40 \mathrm{~g} \mathrm{dcw} / \mathrm{l}$ of biomass with respective light intensities of $400,500,600,200$, and $100 \mu \mathrm{mol} \mathrm{m} \mathrm{s}^{-1}$. Similarly, Wahidin et al. [25] reported a correlation between light intensity and microalgal biomass. Nannochloropsis sp. produces more biomass with $100 \mu \mathrm{mol} \mathrm{m} \mathrm{s}^{-2}$ of light intensity than those with 50 or $200 \mu \mathrm{mol} \mathrm{m} \mathrm{m}^{-1}$. Thus, 

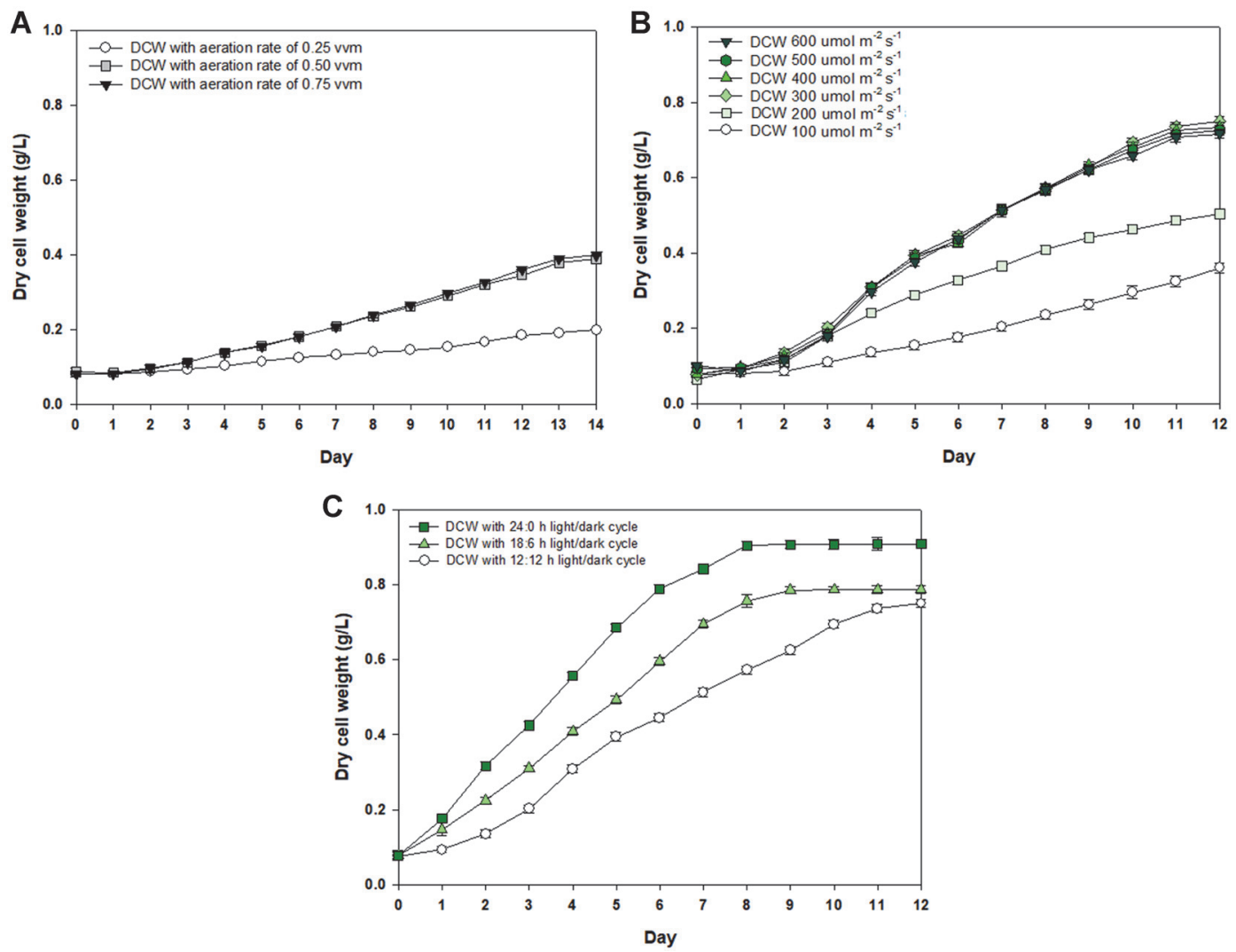

Fig. 2. Optimization of maximum biomass production of $P$. cruentum cultured in $14-\mathrm{L}$ photo-bioreactors under the green LED wavelength with various (A) aeration rates, (B) light intensities alongside $0.75 \mathrm{vvm}$ aeration rate, and (C) photoperiods alongside $0.75 \mathrm{vvm}$ aeration rate and $300 \mu \mathrm{mol} \mathrm{m}^{-2} \mathrm{~s}^{-1}$ light intensity.

microalgae produce large biomass amounts at high light intensities; however, when overexposed to light, cells can be inhibited by additional light. On the other hand, light intensity plays an important role in microalgae cultivation, and the requirements vary greatly depending on depth and density. When microalgae are cultured at high cell concentrations, the light intensity must be increased for light transmission. In our work, the least biomass was produced with the lowest light intensity of $100 \mu \mathrm{mol} \mathrm{m}^{-2} \mathrm{~s}^{-1}$; however, there was no significant difference between the biomass produced at 300,400, 500, and $600 \mu \mathrm{mol} \mathrm{m}^{-2} \mathrm{~s}^{-1}$. Therefore, $300 \mu \mathrm{mol} \mathrm{m}^{-2} \mathrm{~s}^{-1}$ was chosen as the optimal condition for the production of the highest biomass with the lowest power consumption.

\section{Effect of Photoperiod Under Green LED Wavelength}

After determining the optimal aeration rate of $0.75 \mathrm{vvm}$ and light intensity of $300 \mu \mathrm{mol} \mathrm{m}^{-2} \mathrm{~s}^{-1}$, the photoperiod was optimized. Photoperiods of 12:12, 18:6, and 24:0 h light/dark cycles were used under the green LED wavelength. Fig. 2C shows that P. cruentum yielded the highest biomass of $0.91 \mathrm{~g} \mathrm{dcw} / \mathrm{l}$ by day 8 with $24: 0 \mathrm{~h}$ light/ dark cycle, followed by 18:6 h $(0.79 \mathrm{~g} \mathrm{dcw} / \mathrm{l})$ and then $12: 12 \mathrm{~h}(0.75 \mathrm{~g} \mathrm{dcw} / \mathrm{l})$. The biomass productivity of P. cruentum was $0.0625 \mathrm{~g} \mathrm{dcw} / \mathrm{l} / \mathrm{day}$ at day 12 of culture when light intensity was optimized. However, the productivity reached $0.114 \mathrm{~g} \mathrm{dcw} / \mathrm{l} /$ day on day 8 of culture after the optimization of light intensity and photoperiod. In addition, the incubation time of the cells cultured in the 24:0 $\mathrm{h}$ light/dark cycle was shorter than that of the 12:12 h light/dark cycle. The stationary phase was reached by days 12,9 , and 8 with the 12:12 h, 18:6 h, and 24:0 $\mathrm{h}$ light/dark cycles, respectively. The growth rate of biomass changed according to photoperiod. Sirisuk et al. [26] have reported that Phaedactylum tricornutum and Nannochloropsis salina grow faster with a 24:0 h light/ dark cycle than these same species with a 12:12 h light/dark cycle. However, Isochrysis galbana proliferates the most with an 18:6 h light/dark cycle comparing to 12:12, and 24:0 h light/dark cycles. Although excess light has an inhibitory effect on cell growth, $P$. cruentum was not negatively affected by the $24: 0 \mathrm{~h}$ light/dark cycle in this study. Therefore, the 24:0 $\mathrm{h}$ light/dark cycle was selected to produce the highest biomass yield.

\section{Effect of Red LED Light Intensity in Second Phase}

The optimal conditions for biomass production in the first phase of the culture were determined to be $0.75 \mathrm{vvm}$ aeration rate, $300 \mu \mathrm{mol} \mathrm{m}^{-2} \mathrm{~s}^{-1}$ light intensity, and a photoperiod of 24:0 h light/dark cycle under the green LED wavelength. Lipid production was induced with the red LED wavelength in the second phase. Light intensities of $100,200,300,400,500$, and $600 \mu \mathrm{mol} \mathrm{m}^{-2} \mathrm{~s}^{-1}$ were used under the red LED wavelength. The light intensity in the second phase of the culture was evaluated for 3 days to determine the optimal culture time for maximum lipid 
A

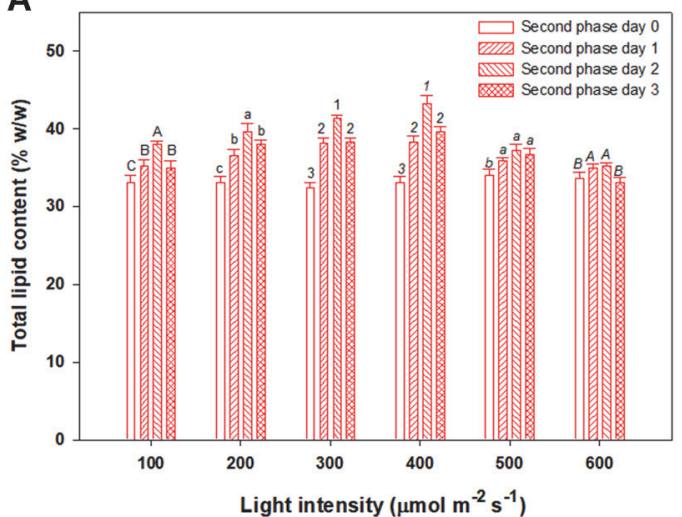

B

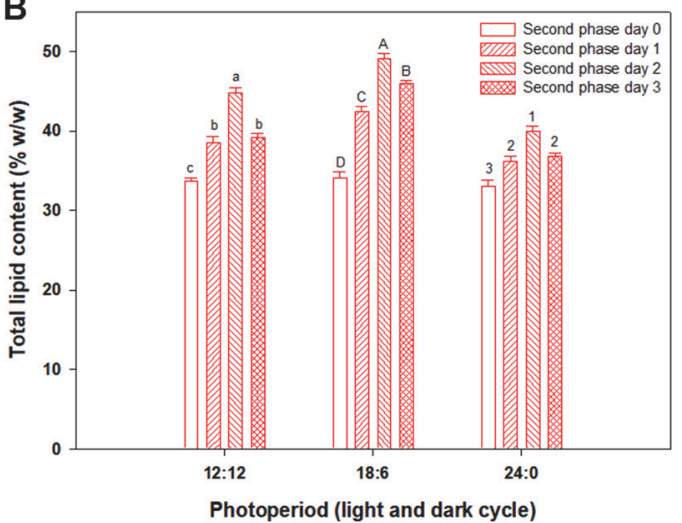

Fig. 3. Total lipid content during the second phase of $P$. cruentum culture under various (A) light intensities and (B) photoperiods of the red LED illumination. Different letters and numbers indicate the significant differences $(p<0.05$, Duncan's test).

production. Fig. 3A shows that the lipid content varied based on the light intensity. P. cruentum showed the highest lipid production of $43.3 \%(\mathrm{w} / \mathrm{w})(0.39 \mathrm{~g} / \mathrm{l})$ with $400 \mu \mathrm{mol} \mathrm{m}^{-2} \mathrm{~s}^{-1}$ of light intensity. The lipid content was increased by $10.3 \%$ compared to $33.0 \%(\mathrm{w} / \mathrm{w})(0.30 \mathrm{~g} / \mathrm{l})$ lipid on day 0 of the second phase culture with light intensity of $400 \mu \mathrm{mol} \mathrm{m} \mathrm{s}^{-2}$, and the lipid productivity was $39.4 \mathrm{mg} / \mathrm{l} /$ day on day 2 of second phase. Maximum total lipid productions of $38.0,39.6,41.3$, and $43.3 \%(\mathrm{w} / \mathrm{w})(0.35,0.36,0.38$, and $0.39 \mathrm{~g} / \mathrm{l})$ were obtained at light intensities of $100,200,300$, and $400 \mu \mathrm{mol} \mathrm{m}^{-2} \mathrm{~s}^{-1}$, respectively. However, light intensities above $500 \mu \mathrm{mol} \mathrm{m}^{-2} \mathrm{~s}^{-1}$ suppressed lipid production. The increase of lipid production upon adjustment of the light intensity is mediated by fatty acid biosynthesis enzymes, such as acetyl CoA carboxylase and ATP/citrate lyase, which are highly active at high lightenergy levels. However, the lipid biosynthesis pathway is inhibited when the light energy exceeds the saturation intensity, thus decreasing lipid production [27]. In addition, Dunstan [28] reported a direct correlation between light intensity and lipid production in microalgae and indicated that the relationship between the light intensity and photosynthesis depends on the chlorophyll type and content of microalgae.

\section{Effect of Photoperiod Under Red LED in Second Phase}

After determining an optimal light intensity of $400 \mu \mathrm{mol} \mathrm{m}^{-2} \mathrm{~s}^{-1}$ in the second phase of the culture, the photoperiod was optimized for the highest lipid production. Photoperiods of 12:12, 18:6, and 24:0 h light/dark cycles were used under the red LED wavelength. The microalgae were cultured for up to 3 days during the second phase to determine the optimal culture time for maximum lipid production. The lipid production of $P$. cruentum during the two-phase culture is shown in Fig. 3B. By day 2 of the second phase of the culture, P. cruentum generated the highest lipid production of $49.1 \%(\mathrm{w} / \mathrm{w})(0.45 \mathrm{~g} / \mathrm{l})$ with the $18: 6 \mathrm{~h}$ light/dark cycle, similar to the trend reported by Wahidin et al. [25]. The lipid content was increased by $15.1 \%$ compared to $34.0 \%(\mathrm{w} / \mathrm{w})(0.31 \mathrm{~g} / \mathrm{l})$ lipid on day 0 of the second phase culture with $16: 8 \mathrm{~h}$ light/dark cycle, and the lipid productivity was $44.7 \mathrm{mg} / \mathrm{l} /$ day on day 2 of second phase. Nannochloropsis sp. produces the highest lipid content of $31.3 \%$ with an 18:6 h light/dark cycle among 12:12, 18:6, and 24:0 $\mathrm{h}$ light/dark cycles. Photoperiods have been reported to induce significant changes in the total chemical compositions, pigment contents, and photosynthetic activities of microalgae [29]. The light source is an essential requirement for the production of triacylglycerides. The required light intensity and photoperiod vary from species to species [30].

\section{Effect of pH on Lipid Content of P. cruentum}

The two-phase culture was performed following the optimization of aeration rate, light intensity, and photoperiod. $P$. cruentum was cultured under a green LED wavelength at an aeration rate of $0.75 \mathrm{vvm}$, a light intensity of $300 \mu \mathrm{mol} \mathrm{m}^{-2} \mathrm{~s}^{-1}$, and under a 24:0 h light/dark cycle for 8 days in the first phase of the culture. The $\mathrm{pH}$ of the first phase was not adjusted by using the seawater. Microalgae growth under varying $\mathrm{pH}$ conditions showed that most marine microalgae produced the highest biomass content in $\mathrm{pH}$ 8.0-9.0 [31]. The seawater used in this study was between $\mathrm{pH}$ 8.3-9.0. Subsequently, the LED wavelength was switched from green to red light with the intensity of $400 \mu \mathrm{mol} \mathrm{m}^{-2} \mathrm{~s}^{-1}$, and the cells were cultured with a photoperiod of 18:6 h light/dark cycle for 2 days in the second phase of the culture to obtain the highest total lipid production as shown in Fig. 4A. The control cultures were not $\mathrm{pH}$-adjusted and their $\mathrm{pH}$ ranged from 8.3 to 8.5 . Various $\mathrm{pH}$ values $(5.0,6.0,7.0,8.0$, and 9.0) were tested for maximum lipid production alongside the control for 3 days in the second phase. Fig. $4 \mathrm{~B}$ shows that P. cruentum produced the highest lipid contents of $51.8 \%(\mathrm{w} / \mathrm{w})(0.47 \mathrm{~g} / \mathrm{l})$ by day 2 of the second phase at $\mathrm{pH} 6.0$, followed by $50.7,50.5,49.5$, and $48.9 \%(\mathrm{w} / \mathrm{w})(0.46,0.46,0.45$, and $0.44 \mathrm{~g} / \mathrm{l})$ of lipid production with $\mathrm{pH} 7.0,8.0$, control, and pH 9.0 at day 2 of the second phase, respectively. P. cruentum produced $18.6 \%$ more lipid on day 2 of the second phase at $\mathrm{pH} 6.0$, compared to $33.6 \%(\mathrm{w} / \mathrm{w})(0.31 \mathrm{~g} / \mathrm{l})$, which was the lipid content on day 0 . In addition, lipid productivity increased from 38.2 to $47.1 \mathrm{mg} / \mathrm{l} /$ day through two-phase culture. High lipid production was obtained at $\mathrm{pH} 5.0$ at $33.3 \%$ on day 0 of the second phase. However, the lipid content decreased over time at pH 5.0. 

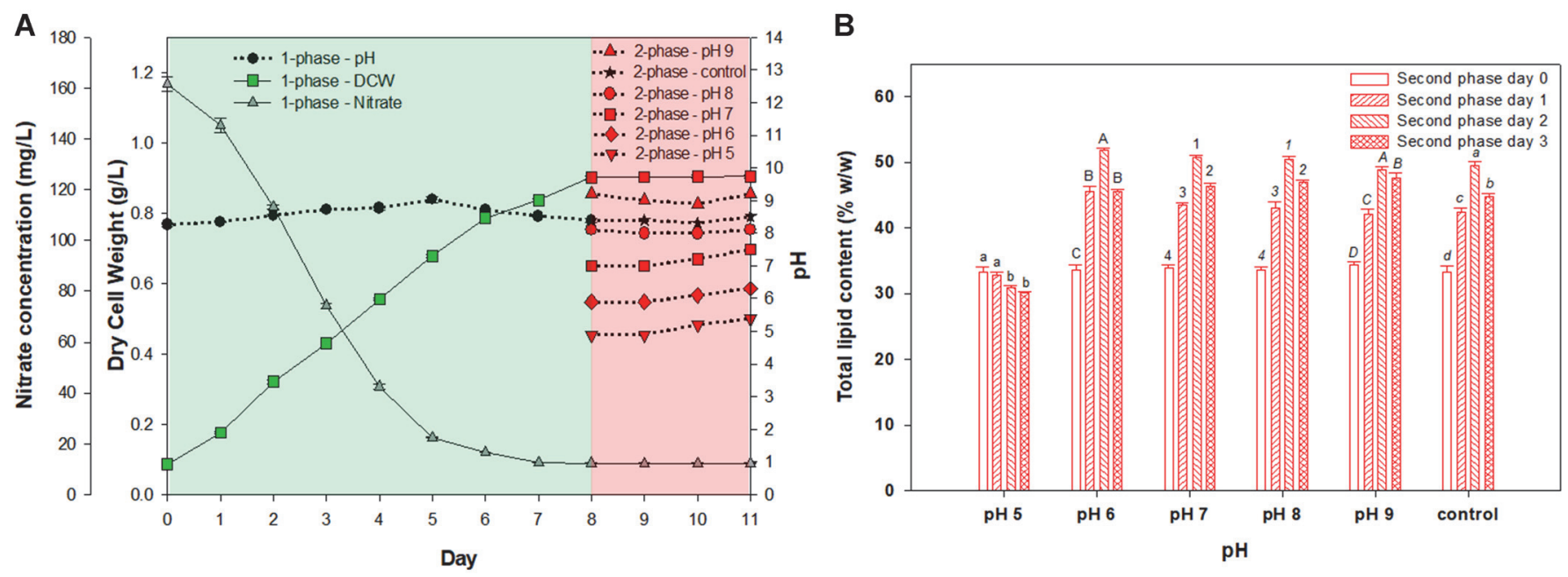

Fig. 4. (A) Time course profile of $P$. cruentum biomass production (line) versus $\mathrm{pH}$ (dotted line) in the second phase. The green and red shades represent the first and second phases of the culture, respectively, and the culture $\mathrm{pH}$ was set to 5.0, 6.0, 7.0, 8.0, or 9.0. (B) The total lipid content during the second phase with various $\mathrm{pH}$ values. Different letters and numbers indicate the significant differences ( $p<0.05$, Duncan's test).

The lipid content increased from $33.5 \%$ to $51.8 \%$ at $\mathrm{pH}$ 6.0. Lipid productivity increased from $0.0381 \mathrm{~g}$ dcw/l/day on day 0 , to $0.0471 \mathrm{~g} \mathrm{dcw} / \mathrm{l} /$ day on day 2 of second phase culture at $\mathrm{pH} 6.0$ by optimizing the light intensity, photoperiod, and $\mathrm{pH}$.

The $\mathrm{pH}$ of the culture affects microalgal lipid production, resulting in increased lipid production under $\mathrm{pH}$ stress [32]. The activity of acetyl-CoA carboxylase, one of the key enzymes in lipid biosynthesis, is known as $\mathrm{pH}-$ dependent [33] and is inhibited at $\mathrm{pH}$ 5.0. In line with this data, adjusting the $\mathrm{pH}$ from the control $\mathrm{pH}$ of 8.5 to $\mathrm{pH}$ 6.0 increased the lipid production in this study.

\section{Effect of pH on Fatty Acid Composition of P. cruentum}

The effect of the $\mathrm{pH}$ on the second-phase culture for the fatty acid composition of P. cruentum biomass was studied. The fatty acid compositions of $P$. cruentum cultured at different $\mathrm{pHs}(5.0,6.0,7.0,8.0$, and 9.0) alongside the control for up to 3 days are shown in Table 1. Relative to the control, there was no significant change for 3 days at pH 5.0 in the fatty acid composition (Tables 1A and 1B). However, the unsaturated fatty acid levels increased to $30.6 \%(144.0 \mathrm{mg} / \mathrm{l}) \mathrm{EPA}$ and $14.5 \%(68.3 \mathrm{mg} / \mathrm{l}) \mathrm{DHA}$ on day 2 at $\mathrm{pH} 6.0$ and $23.5 \%(110 \mathrm{mg} / \mathrm{l}) \mathrm{EPA}$ and $12.4 \%$ $(58.3 \mathrm{mg} / \mathrm{l}) \mathrm{DHA}$ on day 3 at $\mathrm{pH}$ 7.0. The levels of saturated fatty acids, such as stearic acid (C18:0), were decreased as shown in Tables $1 \mathrm{C}$ and $1 \mathrm{D}$. The unsaturated fatty acid level reached to $56.2 \%(\mathrm{w} / \mathrm{w})$ at $\mathrm{pH}$ 6.0. The total unsaturated and saturated fatty acid levels were estimated to be $56.2 \%(\mathrm{w} / \mathrm{w})$ and $43.8 \%(\mathrm{w} / \mathrm{w})$ as shown in Table 1C, respectively. The EPA level reached to $30.6 \%(\mathrm{w} / \mathrm{w})$. At $\mathrm{pH} 7.0$, the saturated fatty acid level decreased to $51.6 \%(\mathrm{w} / \mathrm{w})$ as shown in Table $1 \mathrm{D}$, while the unsaturated fatty acid level increased to $48.4 \%(\mathrm{w} / \mathrm{w})$. In addition, comparing to day 0 of the second-phase culture, the EPA level increased from $8.5 \%$ to $23.6 \%(\mathrm{w} / \mathrm{w})$ as shown in Table 1D. When the culture $\mathrm{pH}$ was increased to 8.0 , the total saturated fatty acid level decreased from $66.8 \%$ to $53.8 \%(\mathrm{w} / \mathrm{w})$, and the unsaturated fatty acid level increased from $33.2 \%$ to $46.2 \%(\mathrm{w} / \mathrm{w})$ as shown in Table $1 \mathrm{E}$. Similar results have been reported for Isochrysis galbana at pHs 6.0, 7.0, and 8.0 [34]. Isochrysis galbana produces higher levels of polyunsaturated fatty acids, such as EPA, and DHA at pH 6.0 than at $\mathrm{pH} 7.0$ or 8.0. Changes in $\mathrm{pH}$ affect the properties of the cell surface, such as adhesion onto the substrata and biomass aggregation [35]. As the $\mathrm{pH}$ decreases, the carboxylate ions receive protons and can be converted to neutral carboxyl groups, whereby the negative charge of the cells is neutralized and the cell dispersion stability is destroyed. This results in aggregation and sedimentation of the cells [36]. Such effects alter the permeation of ions, acids, and bases into the cell, and affect the biochemical metabolism and conformation of macromolecules, as well as the $K_{\mathrm{m}}$ values of enzymes [35]. Microalgal cell membranes are damaged by rapid $\mathrm{pH}$ changes. To prevent this damage, microalgae further accumulate unsaturated fatty acids to increase cell membrane fluidity. Under these cell membrane-damaging stresses, the three desaturase genes D5-desaturase, plastid acyl-ACP D9 desaturase, and microsomal D12desaturase are upregulated to increase the unsaturated fatty acid production. However, excessive drops in $\mathrm{pH}$ make cell membrane maintenance impossible [37]. Therefore, the unsaturated fatty acid composition changes with the $\mathrm{pH}$ of the environment. P. cruentum limits the production of unsaturated fatty acids at $\mathrm{pH}$ below 6.0.

\section{Conclusion}

According to these results, the optimal culture conditions for maximizing biomass yield during the first phase are an aeration rate of $0.75 \mathrm{vvm}$, a light intensity of $300 \mu \mathrm{mol} \mathrm{m}^{-2} \mathrm{~s}^{-1}$, and 24:0 h photoperiod under green $(520 \mathrm{~nm})$ LED light. A maximum biomass production of $0.91 \mathrm{~g} \mathrm{dcw} / 1$ could be achieved. In the second-phase culture, we aimed to increase the lipid content, and the optimal conditions were obtained with the red LED wavelength $(625 \mathrm{~nm})$ at the light intensity of $400 \mu \mathrm{mol} \mathrm{m}^{-2} \mathrm{~s}^{-1}$, under an 18:6 h photoperiod at $\mathrm{pH}$ 6.0. The maximum lipid content reached 
Table 1. Fatty acid methyl ester (FAME) contents as \% of total fatty acids of P. cruentum during the second phase of the culture at (A) control, (B) $\mathrm{pH} \mathrm{5,} \mathrm{(C)} \mathrm{pH} \mathrm{6,} \mathrm{(D)} \mathrm{pH} \mathrm{7,} \mathrm{(E)} \mathrm{pH} \mathrm{8,} \mathrm{and} \mathrm{(F)} \mathrm{pH} 9$.

\begin{tabular}{|c|c|c|c|c|c|c|c|c|c|c|c|c|}
\hline \multirow{2}{*}{$\begin{array}{c}\text { Free fatty acid } \\
\text { (\% of total fatty } \\
\text { acid) }\end{array}$} & \multicolumn{4}{|c|}{ (A) Control } & \multicolumn{4}{|c|}{ (B) $\mathrm{pH} 5$} & \multicolumn{4}{|c|}{ (C) $\mathrm{pH} 6$} \\
\hline & Day 8 & Day 9 & Day 10 & Day 11 & Day 8 & Day 9 & Day 10 & Day 11 & Day 8 & Day 9 & Day 10 & Day 11 \\
\hline $\begin{array}{l}\text { Myristic acid } \\
(\mathrm{C} 14: 0)\end{array}$ & $0.59 \pm 0.01$ & $0.24 \pm 0.02$ & $0.27 \pm 0.05$ & $\overline{0.10 \pm 01}$ & $0.82 \pm 0.05$ & $0.68 \pm 0.08$ & $0.92 \pm 0.02$ & $1.05 \pm 0.01$ & $1.08 \pm 0.01$ & $1.84 \pm 0.01$ & $0.11 \pm 0.01$ & $\overline{0.11 \pm .0 .1}$ \\
\hline $\begin{array}{l}\text { Palmitic acid } \\
(\mathrm{C} 16: 0)\end{array}$ & $6.57 \pm 0.06$ & $6.70 \pm 0.05$ & $7.00 \pm 0.01$ & $4.56 \pm 0.05$ & $5.75 \pm 0.01$ & $5.75 \pm 0.08$ & $6.36 \pm 0.22$ & $7.29 \pm 0.08$ & $6.53 \pm 0.02$ & $2.97 \pm 0.02$ & $2.45 \pm 0.02$ & $2.88 \pm 0.02$ \\
\hline $\begin{array}{l}\text { Palmitoleic acid } \\
(\mathrm{C} 16: 1)\end{array}$ & $0.58 \pm 0.01$ & $0.37 \pm 0.01$ & $0.31 \pm 0.02$ & $1.15 \pm 0.01$ & $0.95 \pm 0.01$ & $0.60 \pm 0.07$ & $0.06 \pm 0.01$ & $0.07 \pm 0.01$ & $0.90 \pm 0.01$ & $2.29 \pm 0.02$ & $1.36 \pm 0.01$ & $1.33 \pm 0.01$ \\
\hline $\begin{array}{l}\text { Stearic acid } \\
(\mathrm{C} 18: 0)\end{array}$ & $56.84 \pm 0.19$ & $47.82 \pm 0.15$ & $43.91 \pm 0.21$ & $48.48 \pm 0.25$ & $55.77 \pm 0.22$ & $55.32 \pm 0.05$ & $58.60 \pm 0.02$ & $59.61 \pm 0.22$ & $53.24 \pm 0.02$ & $46.81 \pm 0.25$ & $36.24 \pm 0.26$ & $38.96 \pm 0.26$ \\
\hline $\begin{array}{l}\text { Oleic acid } \\
(\mathrm{C} 18: 1)\end{array}$ & $11.83 \pm 0.22$ & $12.46 \pm 0.11$ & $12.96 \pm 0.12$ & $5.23 \pm 0.5$ & $12.30 \pm 0.04$ & $11.45 \pm 0.12$ & $10.11 \pm 0.12$ & $11.64 \pm 0.12$ & $12.20 \pm 0.05$ & $4.29 \pm 0.01$ & $2.91 \pm 0.08$ & $6.07 \pm 0.04$ \\
\hline $\begin{array}{l}\text { Linoleic acid } \\
(\mathrm{C} 18: 2)\end{array}$ & $0.71 \pm 0.02$ & $3.08 \pm 0.05$ & $3.40 \pm 0.05$ & $6.76 \pm 0.04$ & $0.73 \pm 0.01$ & $0.69 \pm 0.01$ & $0.35 \pm 0.05$ & $0.07 \pm 0.01$ & $0.78 \pm 0.02$ & $4.29 \pm 0.04$ & $1.60 \pm 0.01$ & $5.73 \pm 0.04$ \\
\hline $\begin{array}{l}\text { Arachicidic acid } \\
(\mathrm{C} 20: 0)\end{array}$ & $0.86 \pm 0.05$ & $0.07 \pm 0.1$ & $0.08 \pm 0.01$ & $0.46 \pm 0.01$ & $0.89 \pm 0.02$ & $0.80 \pm 0.01$ & $1.02 \pm 0.04$ & $1.17 \pm 0.01$ & $0.77 \pm 0.01$ & $0.32 \pm 0.02$ & $0.14 \pm 0.01$ & $0.53 \pm 0.01$ \\
\hline $\begin{array}{l}\text { Linolenic acid } \\
(\mathrm{C} 18: 3)\end{array}$ & $2.36 \pm 0.17$ & $2.77 \pm 0.3$ & $2.89 \pm 0.06$ & $5.06 \pm 0.01$ & $2.46 \pm 0.03$ & $2.72 \pm 0.12$ & $2.93 \pm 0.01$ & $3.42 \pm 0.06$ & $2.35 \pm 0.02$ & $4.85 \pm .03$ & $5.16 \pm 0.04$ & $5.87 \pm 0.02$ \\
\hline $\begin{array}{l}\text { Eicosapentaenoic } \\
\text { acid (C20:5) }\end{array}$ & $8.28 \pm 0.05$ & $11.48 \pm 0.15$ & $12.19 \pm 0.07$ & $10.56 \pm 0.09$ & $9.08 \pm 0.04$ & $10.40 \pm 0.25$ & $9.35 \pm 0.08$ & $9.11 \pm 0.05$ & $9.99 \pm 0.11$ & $17.51 \pm 0.04$ & $30.63 \pm 0.15$ & $21.12 \pm 0.12$ \\
\hline $\begin{array}{l}\text { Behenic acid } \\
(\mathrm{C} 22: 0)\end{array}$ & $2.37 \pm 0.01$ & $3.32 \pm 0.11$ & $3.50 \pm 0.06$ & $6.14 \pm 0.07$ & $2.20 \pm 0.02$ & $1.83 \pm 0.03$ & $1.72 \pm 0.01$ & $1.09 \pm 0.01$ & $3.21 \pm 0.02$ & $2.18 \pm 0.05$ & $4.87 \pm 0.02$ & $7.11 \pm 0.08$ \\
\hline $\begin{array}{l}\text { Docosahexaenoic } \\
\text { acid (C22:6) }\end{array}$ & $9.01 \pm 0.05$ & $11.70 \pm 0.03$ & $13.48 \pm 0.08$ & $11.50 \pm 0.12$ & $9.06 \pm 0.03$ & $9.78 \pm 0.19$ & $8.57 \pm 0.09$ & $5.47 \pm 0.11$ & $8.94 \pm 0.09$ & $12.65 \pm 0.14$ & $14.54 \pm 0.13$ & $10.28 \pm 0.18$ \\
\hline $\begin{array}{l}\text { Saturated fatty } \\
\text { acid }\end{array}$ & 67.23 & 58.15 & 54.76 & 59.73 & 65.42 & 64.38 & 68.63 & 70.22 & 64.53 & 54.12 & 43.80 & 49.59 \\
\hline $\begin{array}{l}\text { Unsaturated } \\
\text { fatty acid }\end{array}$ & 32.77 & 41.85 & 45.24 & 40.27 & 34.58 & 35.62 & 31.37 & 29.78 & 35.17 & 45.88 & 56.20 & 50.41 \\
\hline \multirow{2}{*}{$\begin{array}{c}\text { Free fatty acid } \\
\text { (\% of total fatty } \\
\text { acid) }\end{array}$} & \multicolumn{4}{|c|}{ (D) $\mathrm{pH} 7$} & \multicolumn{4}{|c|}{ (E) $\mathrm{pH} 8$} & \multicolumn{4}{|c|}{ (F) $\mathrm{pH} 9$} \\
\hline & Day 8 & Day 9 & Day 10 & Day 11 & Day 8 & Day 9 & Day 10 & Day 11 & Day 8 & Day 9 & Day 10 & Day 11 \\
\hline $\begin{array}{l}\text { Myristic acid } \\
(\mathrm{C} 14: 0)\end{array}$ & $0.61 \pm 0.01$ & $2.03 \pm 0.01$ & $0.19 \pm 0.01$ & $0.83 \pm 0.05$ & $0.63 \pm 0.01$ & $0.15 \pm 0.01$ & $0.17 \pm 0.01$ & $0.09 \pm 0.01$ & $0.51 \pm 0.01$ & $0.30 \pm 0.01$ & $0.18 \pm 0.01$ & $0.13 \pm 0.01$ \\
\hline $\begin{array}{l}\text { Palmitic acid } \\
(\mathrm{C} 16: 0)\end{array}$ & $6.66 \pm 0.02$ & $3.28 \pm 0.01$ & $2.84 \pm 0.05$ & $4.66 \pm 0.05$ & $6.97 \pm 0.02$ & $5.92 \pm 0.09$ & $6.78 \pm 0.05$ & $4.58 \pm 0.12$ & $6.61 \pm 0.12$ & $6.98 \pm 0.04$ & $7.75 \pm 0.15$ & $4.45 \pm 0.15$ \\
\hline $\begin{array}{l}\text { Palmitoleic acid } \\
\text { (C16:1) }\end{array}$ & $0.65 \pm 0.01$ & $2.77 \pm 0.02$ & $1.24 \pm 0.01$ & $1.36 \pm 0.01$ & $0.62 \pm .0 .01$ & $0.43 \pm 0.01$ & $0.07 \pm 0.01$ & $1.28 \pm 0.03$ & $0.57 \pm 0.01$ & $0.49 \pm 0.06$ & $0.07 \pm 0.01$ & $1.30 \pm 0.09$ \\
\hline $\begin{array}{l}\text { Stearic acid } \\
(\mathrm{C} 18: 0)\end{array}$ & $55.30 \pm 0.28$ & $50.2 \pm 0.20$ & $43.46 \pm 0.18$ & $41.07 \pm 0.19$ & $56.04 \pm 0.19$ & $52.60 \pm 0.32$ & $43.20 \pm 0.19$ & $47.24 \pm 0.26$ & $58.98 \pm 0.31$ & $46.42 \pm 0.19$ & $42.90 \pm 0.22$ & $47.98 \pm 0.22$ \\
\hline $\begin{array}{l}\text { Oleic acid } \\
(\mathrm{C} 18: 1)\end{array}$ & $12.44 \pm 0.25$ & $4.80 \pm 0.04$ & $2.70 \pm 0.01$ & $3.74 \pm 0.05$ & $11.96 \pm 0.15$ & $10.39 \pm 0.17$ & $12.44 \pm 0.11$ & $4.98 \pm 0.05$ & $11.39 \pm 0.09$ & $12.84 \pm 0.11$ & $12.24 \pm 0.09$ & $4.92 \pm 0.18$ \\
\hline $\begin{array}{l}\text { Linoleic acid } \\
(\mathrm{C} 18: 2)\end{array}$ & $0.64 \pm 0.01$ & $3.85 \pm 0.04$ & $2.78 \pm 0.01$ & $2.78 \pm 0.04$ & $0.72 \pm .0 .05$ & $2.43 \pm 0.05$ & $2.90 \pm 0.08$ & $7.13 \pm 0.09$ & $0.67 \pm 0.01$ & $2.84 \pm 0.13$ & $3.07 \pm 0.09$ & $6.91 \pm 0.19$ \\
\hline $\begin{array}{l}\text { Arachicidic acid } \\
\text { (C20:0) }\end{array}$ & $0.92 \pm 0.01$ & $0.29 \pm 0.01$ & $0.19 \pm 0.01$ & $0.46 \pm 0.08$ & $0.88 \pm 0.09$ & $0.02 \pm 0.01$ & $0.13 \pm 0.01$ & $0.43 \pm .01$ & $0.84 \pm 0.01$ & $0.12 \pm \pm 0.01$ & $0.07 \pm 0.01$ & $0.44 \pm 0.01$ \\
\hline $\begin{array}{l}\text { Linolenic acid } \\
(\mathrm{C} 18: 3)\end{array}$ & $2.71 \pm 0.02$ & $4.59 \pm 0.02$ & $5.87 \pm 0.05$ & $5.39 \pm 0.09$ & $2.32 \pm 0.01$ & $2.31 \pm 0.06$ & $3.29 \pm 0.09$ & $5.03 \pm 0.01$ & $2.24 \pm 0.07$ & $2.72 \pm 0.02$ & $2.79 \pm 0.08$ & $4.98 \pm 0.21$ \\
\hline $\begin{array}{l}\text { Eicosapentaenoic } \\
\text { acid (C20:5) }\end{array}$ & $8.45 \pm 0.26$ & $14.57 \pm 0.14$ & $23.58 \pm 0.17$ & $23.54 \pm 0.02$ & $8.34 \pm 0.09$ & $12.18 \pm 0.11$ & $13.03 \pm 0.01$ & $10.97 \pm 0.11$ & $7.13 \pm 0.05$ & $11.90 \pm 0.11$ & $12.54 \pm 0.09$ & $10.24 \pm 0.11$ \\
\hline $\begin{array}{l}\text { Behenic acid } \\
(\mathrm{C} 22: 0)\end{array}$ & $2.43 \pm 0.09$ & $2.12 \pm 0.01$ & $4.96 \pm .0 .14$ & $3.96 \pm 0.01$ & $2.26 \pm 0.01$ & $2.25 \pm 0.01$ & $3.49 \pm 0.07$ & $5.93 \pm 0.08$ & $2.26 \pm 0.09$ & $3.36 \pm 0.05$ & $3.54 \pm 0.01$ & $6.50 \pm 0.02$ \\
\hline $\begin{array}{l}\text { Docosahexaenoic } \\
\text { acid (C22:6) }\end{array}$ & $9.20 \pm 0.17$ & $11.50 \pm 0.21$ & $12.20 \pm 0.05$ & $12.42 \pm 0.12$ & $9.27 \pm .0 .11$ & $11.31 \pm 0.09$ & $14.51 \pm 0.19$ & $12.34 \pm 0.16$ & $8.80 \pm 0.11$ & $12.02 \pm 0.19$ & $14.85 \pm 0.12$ & $12.15 \pm 0.34$ \\
\hline $\begin{array}{l}\text { Saturated fatty } \\
\text { acid }\end{array}$ & 65.92 & 57.92 & 51.64 & 50.97 & 66.78 & 60.95 & 53.76 & 58.27 & 69.20 & 57.19 & 54.44 & 59.50 \\
\hline $\begin{array}{l}\text { Unsaturated } \\
\text { fatty acid }\end{array}$ & 34.08 & 42.08 & 48.36 & 49.03 & 33.22 & 39.05 & 46.24 & 41.73 & 30.80 & 42.81 & 45.56 & 40.50 \\
\hline
\end{tabular}

$51.8 \%(\mathrm{w} / \mathrm{w})$ and productivity reached $47.1 \mathrm{mg} / \mathrm{l} /$ day. In addition, the EPA and DHA productivity were increased to 14.4 and $6.8 \mathrm{mg} / \mathrm{l} /$ day at $\mathrm{pH} 6.0$, respectively. The unsaturated fatty acid productivity reached $26.4 \mathrm{mg} / \mathrm{l} /$ day.

\section{Acknowledgments}

This research was a part of the project titled 'Innovative Marine Production Technology Driven by LED-ICT Convergence Photo-Biology (G22201503892001)', funded by the Ministry of Oceans and Fisheries, Korea.

J. Microbiol. Biotechnol. 


\section{Conflict of Interest}

The authors have no financial conflicts of interest to declare.

\section{References}

1. Ward OP, Singh A. 2005. Omega-3/6 fatty acids: alternative sources of production. Process Biochem. 40: 3627-3652.

2. Brenna JT, Salem N, Sinclair AJ, Cunnane SC. 2009. $\alpha$-Linolenic acid supplementation and conversion to n-3 long-chain polyunsaturated fatty acids in humans. Prostaglandins, Leukot. Essent. Fat. Acids 80: 85-91.

3. Simopoulos AP. 1991. Omega-3 fatty acids in health and disease and in growth and development. Am. J. Clin. Nutr. 54: 438-463.

4. Swanson D, Block R, Mousa SA. 2012. Omega-3 Fatty Acids EPA and DHA: health benefits throughout life. Adv. Nutr. 3: 1-7.

5. Adarme-Vega TC, Lim DKY, Timmins M, Vernen F, Li Y, chenk PM. 2012. Microalgal biofactories: a promising approach towards sustainable omega-3 fatty acid production. Microb. Cell Fact. 96: 1-10.

6. Ryckebosch E, Bruneel C, Termote-Verhalle R, Goiris K, Muylaert K, Foubert I. 2014. Nutritional evaluation of microalgae oils rich in omega-3 long chain polyunsaturated fatty acids as an alternative for fish oil. Food Chem. 160: 393-400.

7. Thurstan RH, Roberts CM. 2014. The past and future of fish consumption: can supplies meet healthy eating recommendations?. Mar. Pollut. Bull. 89: 5-11.

8. Byreddy AR, Yoganantharjah P, Gupta A, Gibert Y, Puri M. 2019. Suitability of novel algal biomass as fish feed: accumulation and distribution of omega-3 long-chain polyunsaturated fatty acid in zebrafish. Appl. Biochem. Biotechnol. 188: 112-123.

9. Cabral EM, Fernandes TJR, Campos SD, Castro-Cunha M, Oliveira MBPP, Cunha LM, et al. 2013. Replacement of fish meal by plant protein sources up to $75 \%$ induces good growth performance without affecting flesh quality in ongrowing Senegalese sole. Aquaculture 380-383: 130-138.

10. Harwood JL, Guschina JA. 2009. The versatility of algae and their lipid metabolism. Biochimie 91: 679-684.

11. Shimizu Y. 1996. Microalgal?: a new perspective. Annu. Rev. Microbiol. 50: 431-465.

12. Tredici MR. 2010. Photobiology of microalgae mass cultures: understanding the tools for the next green revolution. Biofuels 1: $143-162$.

13. Sierra E, Acién FG, Fernández JM, García JL, González C, Molina E. 2008. Characterization of a flat plate photobioreactor for the production of microalgae. Chem. Eng. J. 138: 136-147.

14. Taisir M, Teo CL, Idris A, Yusuf AM. 2016. Cultivation of Nannochloropsis sp. using narrow beam angle light emitting diode in an internally illuminated photobioreactor. Bioresour. Bioprocess 3: 1-8.

15. Sirisuk P, Sunwoo IY, Kim SH, Awah CC, Ra CH, Kim JM, et al. 2018a. Enhancement of biomass, lipids, and polyunsaturated fatty acid (PUFA) production in Nannochloropsis oceanica with a combination of single wavelength light emitting diodes (LEDs) and low temperature in a three-phase culture system. Bioresour. Technol. 270: 504-511.

16. Jung JH, Sirisuk P, Ra CH, Kim JM, Jeong GT, Kim SK. 2019. Effects of green LED light and three stresses on biomass and lipid accumulation with two-phase culture of microalgae. Process Biochem. 77: 93-99.

17. Kim SH, Sunwoo IY, Hong HJ, Awah CC, Jeong GT, Kim SK. 2019. Lipid and unsaturated fatty acid productions from three microalgae using nitrate and light-emitting diodes with complementary LED wavelength in a two-phase culture system. Bioprocess Biosyst. Eng. 42: 1517-1526.

18. Guillard RRL, Ryther JH. 1962. Studies of marine planktonic diatoms: I. Cyclotella nana hustedt, and Detonula confervacea (cleve) gran. Can. J. Microbiol. 8: 229-239.

19. Sakarika M, Kornaros M. 2016. Effect of $\mathrm{pH}$ on growth and lipid accumulation kinetics of the microalga Chlorella vulgaris grown heterotrophically under sulfur limitation. Bioresour. Technol. 219: 694-701.

20. Maksimova IV, Matorin DN, Plekhanov SE, Vladimirova MG, Volgin SL, Maslova IP. 2000. Optimization of maintenance conditions for some microforms of red algae in collections. Russ. J. Plant Physiol. 47: 779-785.

21. Bligh EG, Dyer WJ. 1959. A rapid method of total lipid extraction and purification. Biochem. Physiol. 37: 911-917.

22. Dhup S, Dhawan V. 2014. Effect of nitrogen concentration on lipid productivity and fatty acid composition of Monoraphidium sp. Bioresour. Technol. 152: 572-575.

23. Sánchez Mirón A, García Camacho F, Contreras Gómez A, Grima EM, Chisti Y. 2000. Bubble-column and airlift photobioreactors for algal culture. AIChE J. 46: 1872-1887.

24. Ugwu CU, Aoyagi H, Uchiyama H. 2008. Photobioreactors for mass cultivation of algae, Bioresour. Technol. 99: 4021-4028.

25. Wahidin S, Idris A, Shaleh SRM. 2013. The influence of light intensity and photoperiod on the growth and lipid content of microalgae Nannochloropsis sp. Bioresour. Technol. 129: 7-11.

26. Sirisuk P, Ra CH, Jeong GT, Kim SK. 2018b. Effects of wavelength mixing ratio and photoperiod on microalgal biomass and lipid production in a two-phase culture system using LED illumination. Bioresour. Technol. 253: 175-181.

27. Mondal M, Ghosh A, Tiwari ON, Gayen K, Das P, Mandal MK, et al. 2017. Influence of carbon sources and light intensity on biomass and lipid production of Chlorella sorokiniana BTA 9031 isolated from coalfield under various nutritional modes. Energy Convers. Manag. 145: 247-254.

28. Dunstan WM. 1973. A comparison of the photosynthesis - light intensity relationship in phylogenetically different marine microalgae. J. Exp. Mar. Bio. Ecol. 13: 181-187.

29. Richardson K, Beardall J, Raven JA. 1983. Adaptation of unicellular algae to irradiance: an analysis of strategies. New Phytol.93: 157-191.

30. Harwood JL. 1998. Membrane lipids in algae, in: lipids photosynthesis: structure, function and genetics. Kluwer Academic Publishers, Dordrecht. 6: 53-64.

31. Bartley ML, Boeing WJ, Dungan BN, Holguin FO, Schaub T. 2014. pH effects on growth and lipid accumulation of the biofuel microalgae Nannochloropsis salina and invading organisms. J. Appl. Phycol. 26: 1431-1437.

32. Mandotra SK, Kumar P, Suseela MR, Nayaka S, Ramteke PW. 2016. Evaluation of fatty acid profile and biodiesel properties of microalga Scenedesmus abundans under the influence of phosphorus, pH and light intensities. Bioresour. Technol. 201: 222-229.

33. Thampy KG, Wakil SJ. 1985. Activation of acetyl-CoA carboxylase. Purification and properties of a $\mathrm{Mn}^{2+}$-dependent phosphatase. J. Biol. Chem. 260: 6318-6323.

34. Molina Grima E, Sánchez Pérez JA, García Sánchez JL, García Camacho F, López Alonso D. 1992. EPA from Isochrysis galbana. Growth conditions and productivity. Process Biochem. 27: 299-305.

35. Jiang Y, Chen F. 2000. Effects of medium glucose concentration and $\mathrm{pH}$ on docosahexaenoic acid content of heterotrophic Crypthecodinium cohnii. Process Biochem. 35: 1205-1209.

36. Liu J, Zhu Y, Tao Y, Zhang Y, Li A, Li T, et al. 2013. Freshwater microalgae harvested via flocculation induced by $\mathrm{pH}$ decrease. Biotechnol. Biofuels 6: 96-106.

37. Shekh AY, Shrivastava P, Krishnamurthi K, Mudliar SN, Devi SS, Kanade GS, et al. 2016. Stress enhances poly-unsaturation rich lipid accumulation in Chlorella sp. and Chlamydomonas sp. Biomass Bioenergy 84: 59-66. 